\title{
$\Delta F o s B$, but not FosB, induces delayed apoptosis independent of cell proliferation in the Rat1a embryo cell line
}

K Tahara ${ }^{1,2}$, D Tsuchimoto ${ }^{1,2}$, Y Tominaga ${ }^{1,2}$, S Asoh ${ }^{3}$, S Ohta ${ }^{3}$, M Kitagawa $^{4}$, H Horie ${ }^{5}$, T Kadoya ${ }^{6}$ and Y Nakabeppu ${ }^{*, 1,2}$

1 Division of Neurofunctional Genomics, Department of Immunobiology and Neuroscience, Medical Institute of Bioregulation, Kyushu University, Maidashi Higashi-ku, Fukuoka, Japan

${ }^{2}$ CREST, Japan Science Technology Corporation, Japan

${ }^{3}$ Department of Biochemistry and Cell Biology, Institute of Gerontology, Nippon Medical School, Kosugi-cho, Nakahara, Kawasaki City, Kanagawa, Japan

4 Department of Biochemistry 1, Hamamatsu University School of Medicine, Handa-cho, Hamamatsu, Japan

${ }^{5}$ Advanced Research Center for Biological Science, Waseda University, Higashifushimi, Nishitokyo City, Tokyo, Japan

6 Production Department, R\&D Center, Pharmaceutical Division, Kirin Brewery Co. Ltd, Souja-machi, Maebashi, Gunma, Japan

* Corresponding author: Y Nakabeppu, 3-1-1 Maidashi, Higashi-ku, Fukuoka 812-8582, Japan. Tel: +81 92642 6800; Fax: +81 92642 6791;

E-mail: yusaku@ bioreg.kyushu-u.ac.jp

Received 5.8.02; revised 6.9.02; accepted 16.10 .02

Edited by $\mathrm{H}$ Ichijo

\section{Abstract}

The fates of Rat1a cells expressing FosB and $\Delta F o s B$ as fusion proteins (ER-FosB, ER- $\triangle F o s B$ ) with the ligand binding domain of human estrogen receptor were examined. The binding of estrogen to the fusion proteins resulted in their nuclear translocation and triggered cell proliferation, and thereafter delayed cell death was observed only in cells expressing ER- $\Delta$ FosB. The proliferation of Rat1a cells, but not cell death triggered by ER- $\Delta$ FosB, was completely abolished by butyrolactone I, an inhibitor of cyclinedependent kinases, and was partly suppressed by antisense oligonucleotides against galectin-1, whose expression is induced after estrogen administration. The cell death was accompanied by the activation of caspase- 3 and -9 , the fragmentation of the nuclear genome and cytochrome $c$ release from the mitochondria, and was suppressed by zDEVD-fmk and zLEHD-fmk but not zIETD-fmk. The cell death was not suppressed by exogenous His-PTD-Bcl- $x_{L}$ at all, suggesting involvement of a $\mathrm{Bcl}-\mathrm{x}_{\mathrm{L}}$-resistant pathway for cytochrome $c$ release.

Cell Death and Differentiation (2003) 10, 496-507. doi:10.1038/ sj.cdd. 4401173

Keywords: AP-1; delayed cell death; apoptosis; galectin-1; butyrolactone 1; caspase; $\mathrm{Bcl}-\mathrm{x}_{\mathrm{L}}$; cytochrome $c$
Abbreviations: ER, estrogen receptor; PTD, protein transduction domain; AP-1, activator protein-1; MGMT, $O^{6}$-methylguanine DNA methyltransferase; CDK, cyclin-dependent kinase; PARP, poly(ADP-ribose)polymerase

\section{Introduction}

Jun and Fos family proteins constitute the activator protein-1 $(A P-1)$ transcription factors, ${ }^{1,2}$ which regulate the expressions of various genes that determine cell fates such as cell proliferation, differentiation and programmed cell death., Among four members of fos family genes (c-fos, fos B, fra- 1 , fra-2), only the fos $B$ gene forms two mature mRNAs, fos $B$ and $\Delta f o s B$, by alternative splicing, ${ }^{5}$ each of which encodes more than two polypeptides by the alternative initiation of translation. ${ }^{6,7}$ The $\Delta$ FosB protein encoded by $\Delta$ fos $B$ mRNA lacks the C-terminal 101 amino-acid region of FosB protein encoded by fos $B$ mRNA, which contains several functional motifs responsible for interaction with other transcription factors. ${ }^{5,8}$

The fos $B$ gene products form heterodimers with c-Jun, JunB or JunD proteins in the same manner as C-Fos protein, thereby stimulating the DNA binding activities. FosB dramatically enhances the Jun transcription activating ability acting on AP-1-dependent promoters as does c-Fos, while $\Delta$ FosB suppresses the Jun transcription activating ability. Furthermore, $\triangle$ FosB counteracts the repression of the serumactivated $c$-fos and fos $B$ promoters by either $c$-Fos or FosB iteslf. Thus, fos $B$ gene products are likely to play an important role in the modulation of the gene expression regulated by AP-1. 5

The fos $B$ expression is either absent or barely detectable in most types of adult tissues of rodents, while a basal expression of fos $B$ is detected in some neurons scattered throughout the brain cortex, and in the dorsal portion of the dentate gyrus in the hippocampus. ${ }^{9}$ The expression of the fos $B$ gene, as well as c-fos or c-jun, is both rapidly and transiently induced in brains in response to electrical stimulation, physiological perturbation, stress and psychotropic drugs. $^{9-12}$ The fos $B$ gene products, especially $\Delta \mathrm{FosB}$, have been reported to regulate potentially the neuronal function as well as such cell fates as cell proliferation and differentiation. ${ }^{7,13-15}$

We previously reported that the expression of FosB and $\Delta$ FosB increased in the rat hippocampal $C A 1$ neurons prior to their delayed death after ischemic reperfusion, ${ }^{16}$ thus suggesting that FosB or $\Delta$ FosB may be involved in the regulation of such programmed cell death in addition to regulation of cell proliferation and differentiation. It has been well documented that c-Fos and c-Jun play important roles in 
the induction of apoptosis; ${ }^{4}$ however, there is little literature reporting on the fact that FosB or $\Delta$ FosB regulate the induction of programmed cell death.

In order to examine the possibility as to whether FosB or $\Delta$ FosB modulate such cell fates, we previously developed a conditional regulatory system of FosB and $\triangle \mathrm{FosB}$, as well as other nuclear proteins such as $O^{6}$-methylguanine DNA methyltransferase (MGMT), ${ }^{13,17}$ in which each protein is expressed as a fusion to the ligand binding domain of human estrogen receptor (ER), and the fusion proteins translocate to the nucleus only in the presence of estrogen. Using the ERFosB and ER- $\Delta$ FosB expression system, we demonstrated that $\Delta \mathrm{FosB}$ as well as FosB can both potentially activate the proliferation of quiescent Rat1a and rat 3Y1 cells, rat embryo cell lines, to transit G1, initiate DNA replication and ultimately undergo cell division, at least once. ${ }^{13,15,18}$ Furthermore, we showed that rat $3 \mathrm{Y} 1$ cells expressing ER- $\Delta$ FosB or ER-FosB undergo differentiation after one round of cell division with alterations in their gene expression. ${ }^{15}$

In the present study, using the ER-FosB and ER- $\Delta$ FosB expression system, we demonstrated that the prolonged expression of ER- $\Delta$ FosB, but not ER-FosB, in Rat1a cells induces delayed apoptosis dependent on the activation of caspase- 9 and -3 following the release of mitochondrial cytochrome $c$, after one round of cell proliferation. However, this delayed apoptosis was found to be independent of the cell proliferation.

\section{Results}

\section{ER- $\Delta F o s B$, but not ER-FosB, induces delayed apoptosis following proliferation in quiescent Rat1a cells}

We earlier reported that FosB and $\Delta F o s B$ expressed as fusion proteins (ER-FosB, ER- $\Delta$ FosB) with the ligand binding domain of the human ER in Rat1a cells accumulate in nuclei and form stable complexes with Jun proteins after estrogen treatment. ${ }^{13}$ The nuclear accumulation of ER- $\Delta \mathrm{FosB}$, and to a lesser extent ER-FosB, triggers quiescent cells to complete one cell cycle in the absence of serum within $36 \mathrm{~h} .{ }^{18}$

To evaluate the fates of these cells after the completion of one cell cycle, we further examined the cultures for longer periods. Confluent cultures of Rat1a(ER-FosB), Rat1a(ER$\Delta$ FosB) and Rat1a(ER-MGMT) cells were maintained in a serum-free medium for 2 days. First, we confirmed that the nuclear accumulation of the ER-fusion proteins lasts for at least $76 \mathrm{~h}$ after estrogen administration (Figure 1a). As shown in Figure $1 b$, after serum stimulation each line of cells was observed to divide twice within the first $48 \mathrm{~h}$, and thereafter the cells ceased to proliferate. On estrogen stimulation, the number of Rat1a (ER-FosB) cells doubled within the first $60 \mathrm{~h}$ after exposure to estrogen, and the number of viable cells thereafter slightly decreased. On the other hand, Rat1a (ER$\Delta \mathrm{FosB}$ ) cells treated with estrogen were observed to divide once within the first $36 \mathrm{~h}$ after stimulation, and thereafter most of the living cells not stained with trypan blue apparently disappeared. Accordingly, a significant number of dead cells stained with trypan blue appeared in the culture of Rat1a (ER$\Delta \mathrm{FosB}$ ) cells treated with estrogen, and such dead cells were never observed in any other cultures. These observations were confirmed by analyzing more than three independent cell lines expressing ER-FosB and ER- $\Delta$ FosB (data not shown).

As shown in Figure 1c, fluorochrome staining (Hoechst33258) revealed nuclear condensation and fragmentation in the culture of Rat1a (ER- $\Delta$ FosB) but not Rat1a (ER-FosB) cells, $48 \mathrm{~h}$ after estrogen administration. Furthermore, in the Rat1a (ER- $\Delta$ FosB) cells, electron-dense nuclear inclusions, which are most likely apoptotic bodies, ${ }^{19}$ were observed by electron microscopy (Figure 1d). A flow cytometry analysis revealed that about $16-38 \%$ of Rat1a (ER- $\Delta$ FosB) cells were in the sub-G1 fraction, as hypodiploid cells, 48 and $72 \mathrm{~h}$ after estrogen administration (Figure 1e), but the number of such cells was much smaller in Rat1a (ERFosB) and Rat1a (ER-MGMT) cells. Furthermore, pulse field gel electrophoresis revealed a high molecular weight DNA fragmentation only in the estrogen-treated Rat1a (ER- $\Delta$ FosB) cells (Figure 2a). Low molecular weight oligonucleosomal fragmentation only became evident in Rat1a (ER- $\Delta$ FosB) cells $36 \mathrm{~h}$ after estrogen administration (Figure $2 \mathrm{~b}$ ), thus indicating that delayed cell death is accompanied by the fragmentation of the nuclear genome.

As a result, we concluded that ER- $\Delta$ FosB, but not ER-FosB, induces the delayed apoptosis after one round of cell proliferation in quiescent Rat1a cells.

\section{The delayed apoptosis caused by $\Delta$ FosB is independent of cell proliferation}

We earlier reported that the levels of CDK1, CDK2 and cyclin $A, B, E$ mRNAs increased during the proliferative activation of the quiescent Rat1a cells by ER- $\Delta$ FosB. ${ }^{18}$ Since the sustained activation of cyclin-dependent kinases (CDKs) was reported to induce apoptotic cell death, ${ }^{20,21}$ we further examined whether functions of CDKs are involved in the induction of delayed apoptosis triggered by ER- $\Delta$ FosB. When quiescent Rat1a(ER- $\Delta$ FosB) cells were pretreated with $20 \mu \mathrm{M}$ butyrolactone I, a specific inhibitor for CDK1 and CDK2, ${ }^{22}$ their proliferation was not induced after estrogen administration at all (Figure 3). However, the number of living cells was substantially decreased from $36 \mathrm{~h}$ after estrogen administration. Without estrogen, $20 \mu \mathrm{M}$ butyrolactone I had no toxic effect on the quiescent cells.

We thus concluded that butyrolactone I inhibited cell proliferation, but not the delayed apoptosis triggered by ER$\Delta$ FosB.

\section{Induced expression of galectin-1 in estrogen- treated Rat1a(ER- $\Delta$ FosB) cells}

We recently reported that the expression of galectin-1, which is known to promote cell proliferation or apoptosis, ${ }^{23,24}$ is upregulated downstream of $\triangle \mathrm{FosB}$ in rat $3 \mathrm{Y} 1$ embryo cell line. ${ }^{15}$ We next examined the expression of galectin- 1 in the Rat1a(ER- $\Delta$ FosB) cells (Figure 4). The levels of galectin-1 protein determined by Western blotting were significantly higher in the quiescent Rat1a(ER-FosB) and Rat1a(ERMGMT) cells than in the quiescent Rat1a(ER- $\Delta$ FosB) cells. The level of galectin-1 in the latter cells also slightly increased 

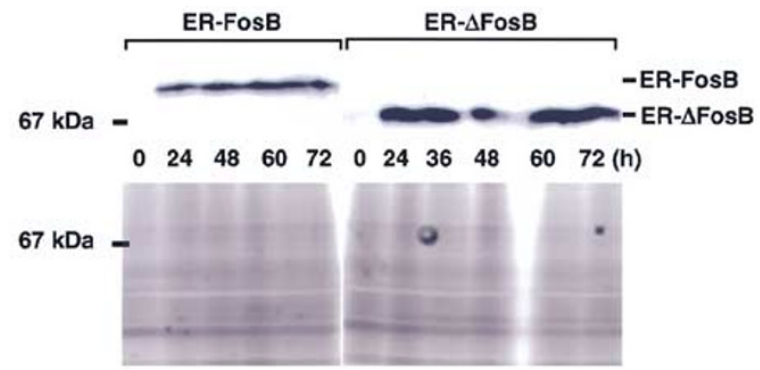

b
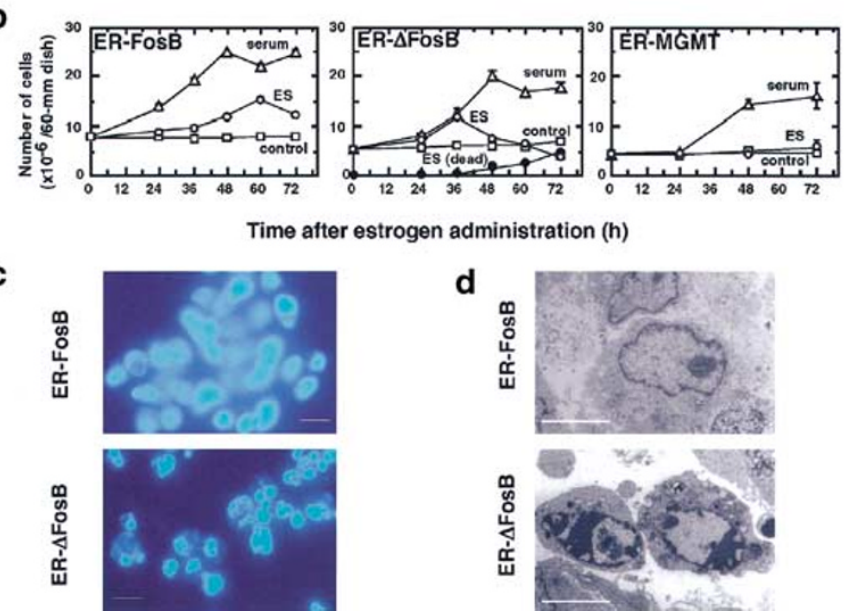
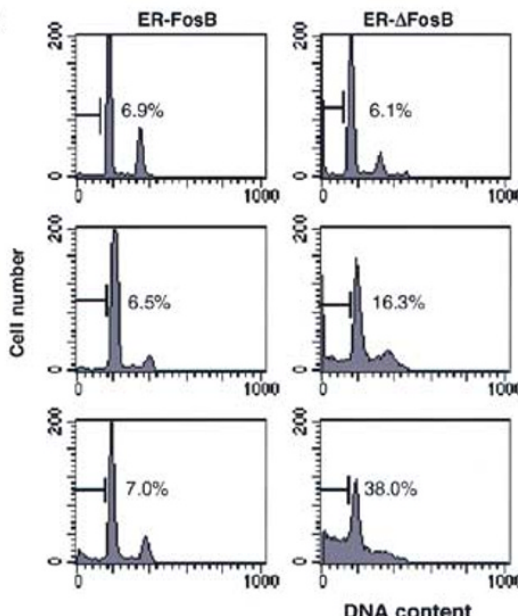
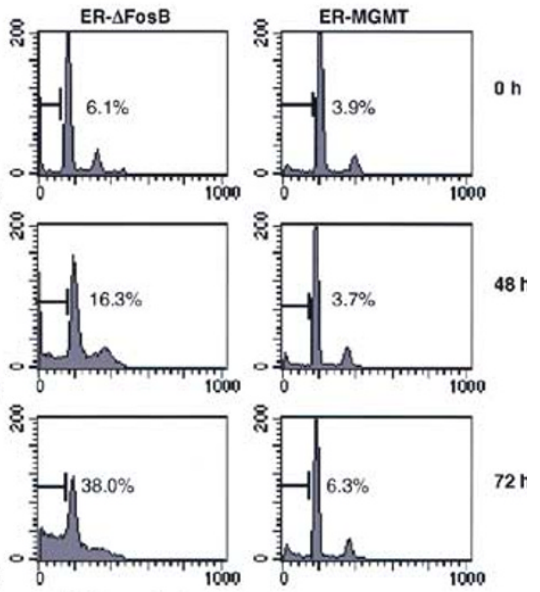

Figure 1 ER- $\Delta$ FosB induces delayed cell death following one round of cell proliferation triggered by estrogen administration. (a) Nuclear translocation of ER-FosB and ER- $\Delta$ FosB fusion proteins after estrogen treatment. Quiescent Rat1a(ER-FosB) and Rat1a (ER- $\Delta$ FosB) cells were treated with $1 \mu$ M estrogen, and harvested at the times noted. Nuclear lysates (1 u A260) were prepared and subjected to Western blotting with anti-FosB (N). The gels stained before transfer are shown in the lower panel. (b) Quiescent Rat1a(ER-FosB), Rat1a(ER- $\Delta$ FosB) and Rat1a(ER-MGMT) cells were treated with $20 \%$ serum or $1 \mu \mathrm{M}$ estrogen and harvested at the times noted. The cells were stained with trypan blue, and living cells (open symbols) and dead cells (closed symbols) were counted. Square, no treatment (control); circle, $1 \mu \mathrm{M}$ estrogen treatment (ES); triangle, $20 \%$ serum stimulation (serum). (c) Fluorochrome staining of Rat1a(ER- $\Delta$ FosB) and Rat1a(ER-FosB) cells after estorgen treatment. Quiescent Rat1a(ER-FosB) and Rat1a(ER- $\Delta$ FosB) cells were treated with $1 \mu \mathrm{M}$ estrogen for $48 \mathrm{~h}$, and were then fixed and stained with Hoechst33258. Bars indicate $10 \mu \mathrm{m}(\times 400)$. (d) Electron microscopy. Rat1a(ER- $\Delta$ FosB) and Rat1a(ER-FosB) cells were treated with $1 \mu \mathrm{M}$ estorgen for $48 \mathrm{~h}$, and were then processed for electron microscopy as described in Materials and Methods. Bars indicate $5 \mu \mathrm{m}$ ( $\times 3000)$. (e) Detection of hypodiploid cells. Quiescent Rat1a(ER-FosB), Rat1a(ER- $\Delta$ FosB) and Rat1a(ER-MGMT) cells were treated with $1 \mu \mathrm{M}$ estrogen for the times noted, and isolated nuclei were subjected to flow cytometry after staining with propidium iodide. The percentages of nuclei in the sub-G1 fraction are shown

soon after estrogen administration, and thereafter further increased until it reached a level equivalent to that in the former cells (Figure 4a). In contrast to the protein levels, Northern blotting revealed the levels of galectin-1 mRNA in three cell lines to be equivalent and constant throughout the experiments (Figure 4b, c).

\section{Galectin-1 is partly responsible for the proliferation of Rat1a(ER- $\Delta$ FosB) cells, but not for their apoptosis}

In order to examine the biological significance of the altered expression of galectin-1 in Rat1a(ER- $\Delta$ FosB) cells, antisense oligonucleotides against galectin-1 mRNA were applied to the cells (Figure 5). The level of galectin-1 protein was significantly downregulated in the cells receiving antisense oligonucleotides but not random oligonucleotides, from 36 to $72 \mathrm{~h}$ after estrogen administration (Figure 5a).
The proliferation of quiescent Rat $1 \mathrm{a}(\mathrm{ER}-\Delta \mathrm{FosB})$ cells induced by estrogen administration was partially suppressed in the culture receiving antisense oligonucleotides but not random oligonucleotides (Figure $5 \mathrm{~b}$ ). In these experiments, the number of living cells not stained by trypan blue did not apparently decrease $72 \mathrm{~h}$ after estrogen administration; however, the cells brightly stained by Hoechst33342 and hypodiploidic cells in the sub-G1 fraction significantly increased even in the culture that received antisense oligonucleotides $48 \mathrm{~h}$ after estrogen administration (Figure $5 \mathrm{c}$ ), thus indicating that the delayed apoptosis was not nullified by the antisense oligonucleotides.

In the presence of $100 \mathrm{mM}$ lactose but not fucose, the proliferation of the quiescent Rat $1 \mathrm{a}(\mathrm{ER}-\Delta \mathrm{FosB})$ cells induced by estrogen administration was also partially suppressed (Figure 5d). Again, the delayed cell death was not suppressed in the presence of lactose (data not shown). These results indicate that galectin-1, especially its function as lectin, is partly responsible for the proliferation of Rat $1 \mathrm{a}(\mathrm{ER}-\Delta \mathrm{FosB})$ cells but not for the delayed apoptosis triggered by $\Delta \mathrm{FosB}$. 
a

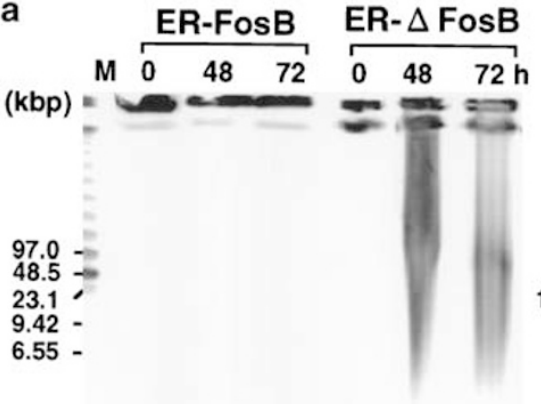

b

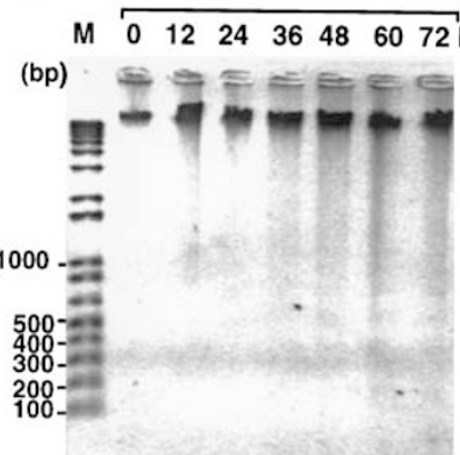

ER-FosB

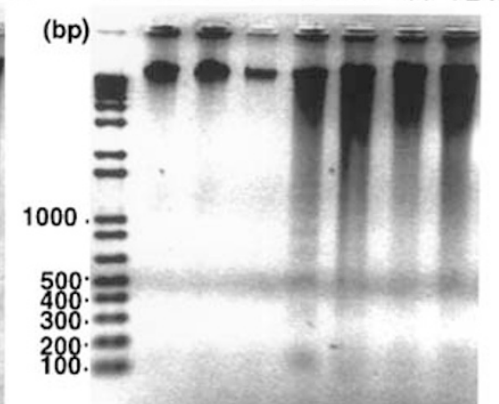

Figure 2 Fragmentation of nuclear DNA in Rat1a(ER- $\Delta$ FosB) cells during the delayed cell death triggered by estrogen. (a) High molecular weight DNA fragmentation. Quiescent Rat1a(ER-FosB), Rat1a(ER- $\Delta$ FosB) and Rat1a(ER-MGMT) cells were treated with $1 \mu \mathrm{M}$ estrogen for the times noted, and equal numbers of cells were subjected to pulse-field gel electrophoresis. (b) Low molecular weight oligonucleosomal fragmentation. Quiescent Rat1a(ER-FosB) and Rat1a(ER- $\Delta$ FosB) cells were treated with $1 \mu \mathrm{M}$ estrogen for the times noted, and the low molecular weight DNA isolated from equal number of cells for each sample were subjected to $1 \%$ agarose gel electrophoresis

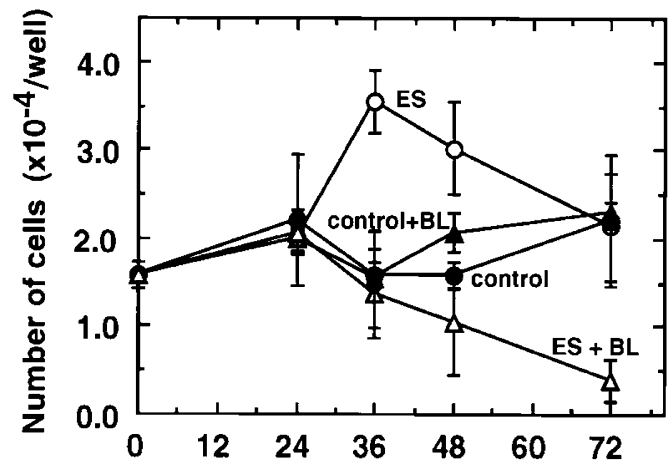

Time after estrogen administration (h)

Figure 3 Butyrolactone I inhibits the proliferation of Rat1a(ER- $\Delta$ FosB) cells but not cell death by ER- $\Delta$ FosB. Quiescent Rat1a(ER- $\Delta$ FosB) cells were pretreated with (triangle) or without (circle) $20 \mu \mathrm{M}$ butyrolactone I (BL) for $2 \mathrm{~h}$, and then treated further with (open symbol) or without (closed symbol) $1 \mu \mathrm{M}$ estrogen (ES). The cells were harvested at the times noted, and living cells not stained with trypan blue were counted. Control, no treatment

\section{The delayed apoptosis caused by ER- $\Delta$ FosB is caspase-3- and caspase-9-dependent}

In the Rat1a(ER- $\Delta$ FosB) but not Rat1a(ER-FosB) and Rat1a(ER-MGMT) cells, the $85-k D a$ processed form of poly(ADP-ribose)polymerase (PARP) was detected $48 \mathrm{~h}$ after estrogen administration (Figure 6a), thus suggesting that caspase- 3 is activated during the delayed apoptosis induced by ER- $\Delta$ FosB. ${ }^{25}$ A 32-kDa procaspase-3 was detected in all of the three cell lines, and its levels most likely increased in Rat1a(ER-FosB) and Rat1a(ER- $\Delta$ FosB) but not Rat1a(ERMGMT) cells (Figure 6b). In Rat1a(ER- $\Delta$ FosB) cells, a smaller band corresponding to a 24-kDa polypeptide, which seems to be the partially processed caspase- 3 intermediate form (the prodomain and the large subunit), ${ }^{26}$ significantly increased from 48 and $72 \mathrm{~h}$ after estrogen administration. Furthermore, the longer exposure, shown in the lower panel of Figure $6 \mathrm{~b}$, revealed that the 20 - and $17-\mathrm{kDa}$ bands corresponding to the large subunit of caspase- $3,{ }^{26}$ which is also evident in the cells treated with actinomycin $\mathrm{D}$, were detected in estrogen-treated
Rat1a(ER- $\Delta$ FosB) but not Rat1a(ER-MGMT) and Rat1a(ERFosB) cells.

No enzyme activity cleaving DEVD-AFC, a substrate for the caspase-3 and related proteases, ${ }^{27}$ was detected in the quiescent Rat1a cells, but the activity cleaving DEVD-AFC significantly increased only in the Rat1a(ER- $\Delta$ FosB) cells from 48 to $72 \mathrm{~h}$ after estrogen administration (Figure $6 \mathrm{c}$ ). In addition, the activity of hydrolyzing LEHD-AFC, a substrate for the caspase- $9,{ }^{27}$ also significantly increased only in the Rat1a(ER- $\Delta$ FosB) cells from 48 to $72 \mathrm{~h}$ after estrogen administration (Figure 6c). We performed a Western blot analysis for caspase-9 and detected $45-\mathrm{kDa}$ procaspase-9; however, processed forms of caspase- 9 were barely detectable in any cell lines using the polyclonal antibodies against caspase-9 p10 (H83) (data not shown).

Although substantial levels of activity hydrolyzing LETDAFC, a substrate for the caspase-8, were detected in Rat1a(ER-FosB), Rat1a(ER- $\Delta$ FosB) and Rat1a(ER-MGMT) cells in the absence of estrogen, the levels changed similarly in all three cell lines after estrogen administration (Figure 6c). Similar results were obtained when IETD-AFC was used as a substrate (data not shown).

To confirm that caspase- 3 and caspase- 9 are indeed involved in the process of the delayed apoptosis induced by $\Delta$ FosB, inhibitors for the caspases were applied to the Rat1a(ER- $\Delta$ FosB) cells. As shown in Figure $7 a, b$, the number of living cells not stained by trypan blue was almost completely restored in the presence of both zDEVD-fmk and zLEHD-fmk, an inhibitor for caspase-3 and caspase-9, respectively. ${ }^{28}$ However, in the presence of an inhibitor for caspase-8, zIETD$\mathrm{fmk}$, cell death was not prohibited at all (Figure 7c).

We thus conclude that caspase- 3 and Caspase- 9 are activated and involved in the delayed apoptosis of Rat1a cells triggered by ER- $\Delta$ FosB.

\section{Cytochrome $c$ is released from the mitochondria during the delayed apoptosis caused by ER- $\Delta$ FosB}

Since the activation of caspase- 9 is mostly dependent on cytochrome $c$ released from mitochondria and Apaf- $1,{ }^{29}$ we 
a
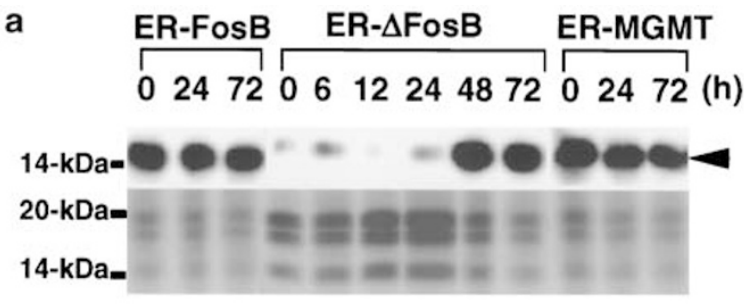

b
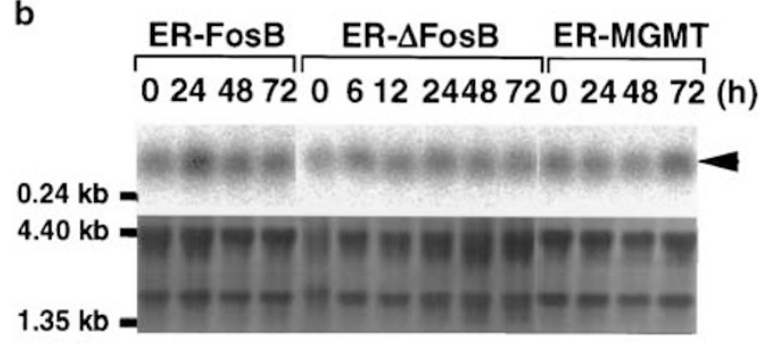

c

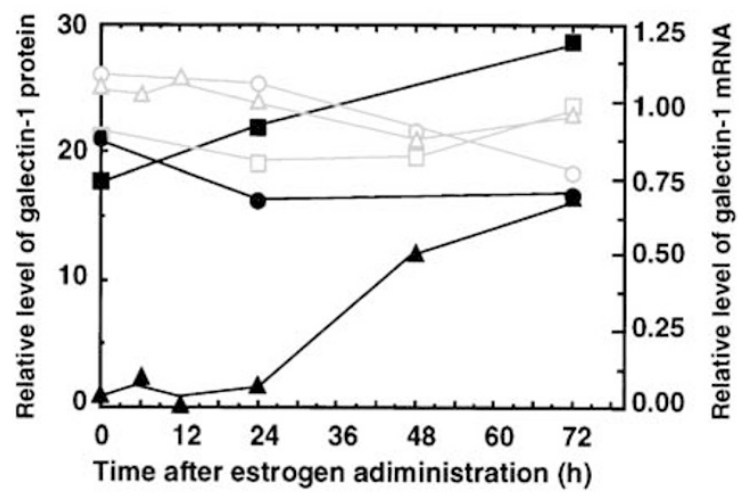

- ER-FosB $\Delta \triangle$ ER- $\triangle$ FosB $\square$ ER-MGMT

Figure 4 Induced expression of galectin-1 in the estrogen-treated Rat1a(ER$\Delta$ FosB) cells. (a) Western blotting analysis. Quiescent Rat1a(ER- $\Delta$ FosB), Rat1a(ER-FosB) and Rat1a(ER-MGMT) cells were treated with $1 \mu \mathrm{M}$ estrogen and harvested at the times noted, and cell lysates (10 $\mu \mathrm{g}$ protein) were subjected to Western blotting with anti-rhGal-1 (upper panel). The gels stained before transfer are shown in the lower panel. An arrowhead indicates the $14-\mathrm{kDa}$ galectin-1. (b) A Northern blotting analysis of galectin-1 mRNA. Total RNA were prepared from the cultures treated as in (a), and were subjected to Northern blotting for galectin-1 (upper panel). An arrowhead indicates the $0.65 \mathrm{~kb}$ galectin1 mRNA. In order to confirm the amounts of RNA on the blots, the membranes were stained with methylene blue (lower panel). (c) Relative levels of galectin-1 mRNA and protein. Ratio of the relative amounts of galectin-1 protein (closed symbols with solid lines) and mRNA (open symbols with gray lines) normalized by total protein or RNA to that in the quiescent cells is shown: squares, Rat1a(ERMGMT); circles, Rat1a(ER-FosB); triangles, Rat1a(ER- $\Delta$ FosB) cells

examined the release of cytochrome $c$ in the Rat1a(ER$\Delta$ FosB) cells (Figure 8). A significant amount of cytochrome $c$ was released in Rat1a(ER- $\Delta$ FosB) cells, but not in Rat1a(ERFosB) or Rat1a(ER-MGMT) cells, from 48 to $72 \mathrm{~h}$ after estrogen administration. The level of released cytochrome $c$ in the Rat1a(ER- $\Delta$ FosB) cells was higher in the estrogentreated cells than in the staurosporine-treated cells (Figure 8 , lane S).

We then examined the levels of proapoptotic and antiapoptotic proteins such as Bad, Bax, Bid, Bcl-2 and Bcl- $\mathrm{x}_{\mathrm{L}}$, which are known to be involved in the regulation of cytochrome $c$ release from mitochondria, ${ }^{30}$ by Western blotting. Substantial levels of these proteins were detected in Rat1a(ER-FosB), Rat1a(ER- $\Delta$ FosB) and Rat1a(ERMGMT) cells with or without estrogen treatment (data not shown), thus indicating that FosB or $\triangle$ FosB did not alter the expression of these proteins.

In order to examine whether the delayed cell death caused by $\Delta$ FosB is suppressed by increasing the intracellular level of antiapoptotic protein, Bcl- $\mathrm{x}_{\mathrm{L}}$, we applied His-PTD-Bcl- $\mathrm{x}_{\mathrm{L}}$ fusion protein, in which the 11-amino-acid protein transduction domain (PTD) of the HIV/TAT protein was fused to $\mathrm{Bcl}-\mathrm{x}_{\mathrm{L}}$ protein, ${ }^{31}$ to the culture of Rat $1 \mathrm{a}$ (ER- $\Delta$ FosB) cells. Although it has been shown that administration of the PTD-Bcl- $x_{L}$ fusion protein effectively suppresses cytochrome $c$ release and cell death induced by staurosporine in cultured neurons, ${ }^{32}$ we first applied the fusion protein to the culture of Rat $1 a(E R-\Delta F o s B)$ cells treated with staurosporine to confirm its potency. As shown in Table 1, in the presence of 84 or $758 \mathrm{nM}$ of His-PTD$\mathrm{Bcl}-\mathrm{x}_{\mathrm{L}}$ protein, the fraction of apoptotic cells revealed by fluorochrome staining decreased from $40 \%$ to less than $30 \%$ in the culture of staurosporine-treated Rat1a(ER- $\Delta$ FosB) cells, thus indicating that the staurosporine-induced cell death is partly suppressed by the His-PTD-Bcl- $x_{\mathrm{L}}$. However, the delayed apoptosis induced by ER- $\triangle$ FosB was not suppressed by His-PTD-Bcl- $x_{L}$ at all, even when $600 \mathrm{nM}$ of His-PTD-Bcl- $\mathrm{x}_{\mathrm{L}}$ was administered into the culture $2 \mathrm{~h}$ before estrogen treatment or 12 and $24 \mathrm{~h}$ after estrogen treatment (Table 2).

\section{Discussion}

In the present study, we demonstrated that the prolonged nuclear localization of ER- $\Delta \mathrm{FosB}$, an estrogen-dependent form of a naturally occurring truncated form of FosB, triggers the delayed apoptosis in rat embryo cell line Rat1a cells. In addition, we also showed that the delayed apoptosis occurs in the mitochondrial pathway which is dependent on caspase- 9 and -3 but is not suppressed by exogenous $\mathrm{Bcl}-\mathrm{x}_{\mathrm{L}}$.

$\triangle \mathrm{FosB}$ and FosB, have both been shown to trigger proliferation of quiescent Rat1a and rat $3 Y 1$ cells; ${ }^{13,15}$ however, these two cell lines exhibited different cell fates with a prolonged expression of $\Delta \mathrm{FosB}$ or FosB. Rat $3 \mathrm{Y} 1$ cells expressing ER- $\Delta$ FosB, and to a lesser extent ER-FosB, undergo differentiation after one round of cell proliferation with an alteration of gene expression, ${ }^{15}$ while Rat 1 a cells with ER$\Delta$ FosB, but not ER-FosB, undergo delayed apoptosis after one round of cell proliferation. Both cell lines were established from rat embryos; however, their different responses to FosB and $\Delta$ FosB indicate that their cell fates are predetermined and can be triggered by FosB or $\Delta$ FosB. In Rat1a cells, the expression of FosB and $\Delta$ FosB results in different responses, with the former showing only proliferative activation, while the other shows delayed apoptosis after limited proliferation, thus indicating that the C-terminal transactivating domain of FosB, which is missing in $\Delta \mathrm{FosB},{ }^{5}$ may transactivate some genes that can suppress delayed apoptosis. If this is the case, then one can expect that the apoptosis by $\Delta \mathrm{FosB}$ can be suppressed by an overexpression of FosB; however, we could not attain such an overexpresion of FosB or ER-FosB in 
a
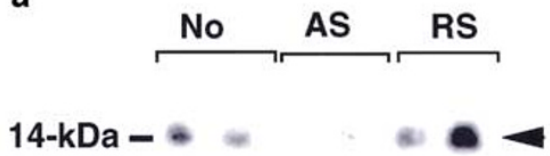

$367236723672(h)$

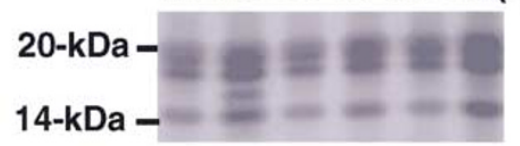

b

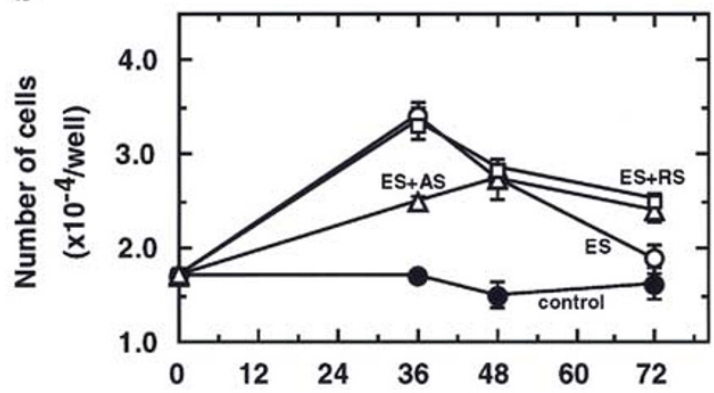

Time after estrogen stimulaiton (h)
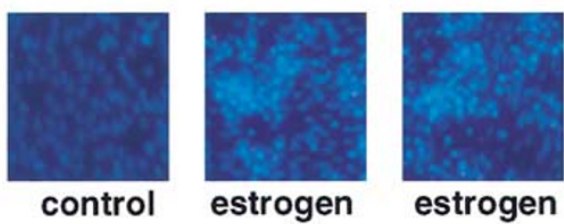

AS

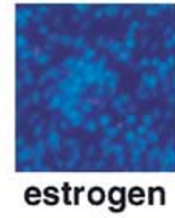

$+$

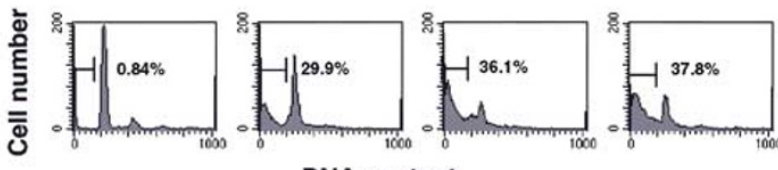

DNA content

d

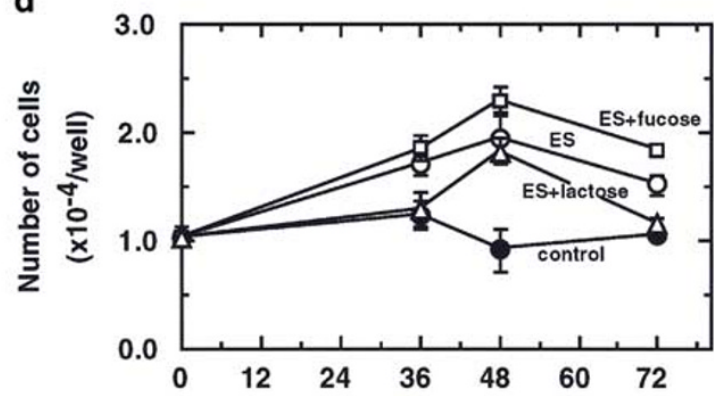

Time after estrogen stimulation (h)

Figure 5 Galectin-1 is partly responsible for the proliferation of Rat1a(ER- $\Delta$ FosB) cells, but not their cell death triggered by estrogen. (a) Antisense oligonucleotide for galectin-1 mRNA suppresses the expression of galectin-1 in Rat1a(ER- $\Delta$ FosB) cells treated with estrogen. Quiescent Rat1a(ER- $\Delta$ FosB) cells were pretreated with $30 \mathrm{nM}$ antisense (AS) or random (RS) oligonucleotides for galectin-1 mRNA for $2 \mathrm{~h}$, and then were treated further with $1 \mu \mathrm{M}$ estrogen. The cells were harvested at the times noted, and cell lysates (10 $\mu$ g protein) were subjected to Western blotting with anti-rhGal-1. No oligonucleotides were administered before estrogen treatment (No). (b) Antisense oligonucleotide for galectin-1 mRNA partly suppresses proliferation of Rat1a(ER- $\Delta$ FosB) cells triggered by estrogen. Quiescent Rat1a(ER- $\Delta$ FosB) cells were pretreated without (circle) or with $30 \mathrm{nM}$ antisense (AS) (triangle) or random (RS) (square) oligonucleotides for $2 \mathrm{~h}$, and were then further treated with (open circle, triangle and square) or without (closed circle) $1 \mu \mathrm{M}$ estrogen (ES). The cells were harvested at the times noted, and the living cells not stained with trypan blue were counted. Control, no treatment. (c) Antisense oligonucleotide for galectin-1 mRNA does not suppress the delayed cell death of Rat1a(ER- $\Delta$ FosB) cells triggered by estrogen. A part of the cells prepared as in (b) were stained with Hoechst33342 $48 \mathrm{~h}$ after estrogen treatment (upper panel), and the rest of the cells were subjected to flow cytometry as shown in Figure 1 (lower panel). Control, no oligonucleotide without $1 \mu \mathrm{M}$ estrogen; estrogen, no oligonucleotide with $1 \mu \mathrm{M}$ estrogen; estrogen+AS, $30 \mathrm{nM}$ antisense oligonucleotides with $1 \mu \mathrm{M}$ estrogen; estrogen+RS, $30 \mathrm{nM}$ random oligonucleotides with $1 \mu \mathrm{M}$ estrogen. Magnification $\times 200$. The percentages of nuclei in the sub-G1 fraction are shown. (d) Lactose, but not fucose, partly suppresses the proliferation of Rat1a(ER- $\Delta$ FosB) cells triggered by estrogen. Quiescent Rat1a(ER- $\Delta$ FosB) cells were pretreated with $100 \mathrm{mM}$ lactose (triangle) or fucose (square) for $2 \mathrm{~h}$, and then treated further with $1 \mu \mathrm{M}$ estrogen (ES). The cells were harvested at the times noted, and living cells not stained with trypan blue were counted. Open circle, no saccharides with $1 \mu \mathrm{M}$ estrogen; closed circle, no saccharides without $1 \mu \mathrm{M}$ estrogen (control)

the Rat1a(ER- $\Delta$ FosB) cells (Tahara et al., unpublished data). This may be because FosB is significantly unstable while $\Delta \mathrm{FosB}$ is quite stable in vivo. ${ }^{6}$

Contrary to our observation, Yamamura et al. ${ }^{33}$ reported that FosB, but not $\triangle \mathrm{FosB}$, promotes programmed cell death triggered by TGF- $\beta$, while $\Delta$ FosB counteracts the FosB function. We may suggest that these different responses of cells to FosB and $\triangle F$ osB are cell-type dependent, that is, FosB or $\triangle \mathrm{FosB}$ can only trigger the genomic response that is predetermined in each cell type. For example, rat 3Y1 cells, but not Rat1a cells, differentiate after a limited proliferation upon expression of either FosB or $\Delta$ FosB. ${ }^{15}$

The cell proliferation triggered by ER- $\Delta$ FosB is accompanied by an increased expression of cyclins and CDKs, such as cycline $\mathrm{A}, \mathrm{B}, \mathrm{E}$ and $\mathrm{CDK} 1, \mathrm{CDK} 2$. $^{18}$ Our present results indicate that cell proliferation is completely dependent on the CDKs; however, delayed apoptosis is independent of the CDK functions. As a result, the delayed apoptosis triggered by
$\Delta$ FosB occurs through some different pathway from that such as Fas-induced apoptosis in hematopoietic cells, which is CDK-dependent. ${ }^{21}$ In the presence of butyrolactone I, the cell death triggered by $\mathrm{ER}-\Delta \mathrm{FosB}$ also progressed in a delayed manner, thus suggesting that $\Delta F o s B$ induces delayed apoptosis independent of cell proliferation.

In rat $3 Y 1$ cells, as one of the downstream targets for $\Delta$ FosB, we identified galectin-1, a 14-kDa $\beta$-D-galactoside binding lectin whose expression was upregulated in the posttranscriptional processes. ${ }^{15}$ Since galectin- 1 has been shown to play an important role in both the regulation of apoptosis and cell proliferation, ${ }^{23,24,34,35}$ we examined the expression level of galectin-1 in Rat1a cells. Galectin-1, which is constitutively expressed in Rat1a cells expressing ER-FosB or ER-MGMT, is barely detectable in Rat1a(ER- $\Delta$ FosB) cells without estrogen, and is highly induced after estrogen treatment, thus confirming that $\triangle F o s B$ does alter the galectin-1 expression even in Rat1a cells. The knockdown 


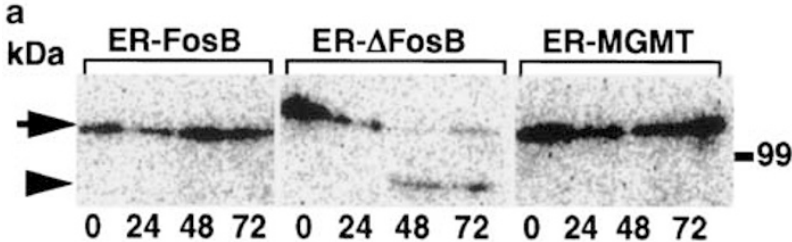

C

Time after estrogen administration (h)
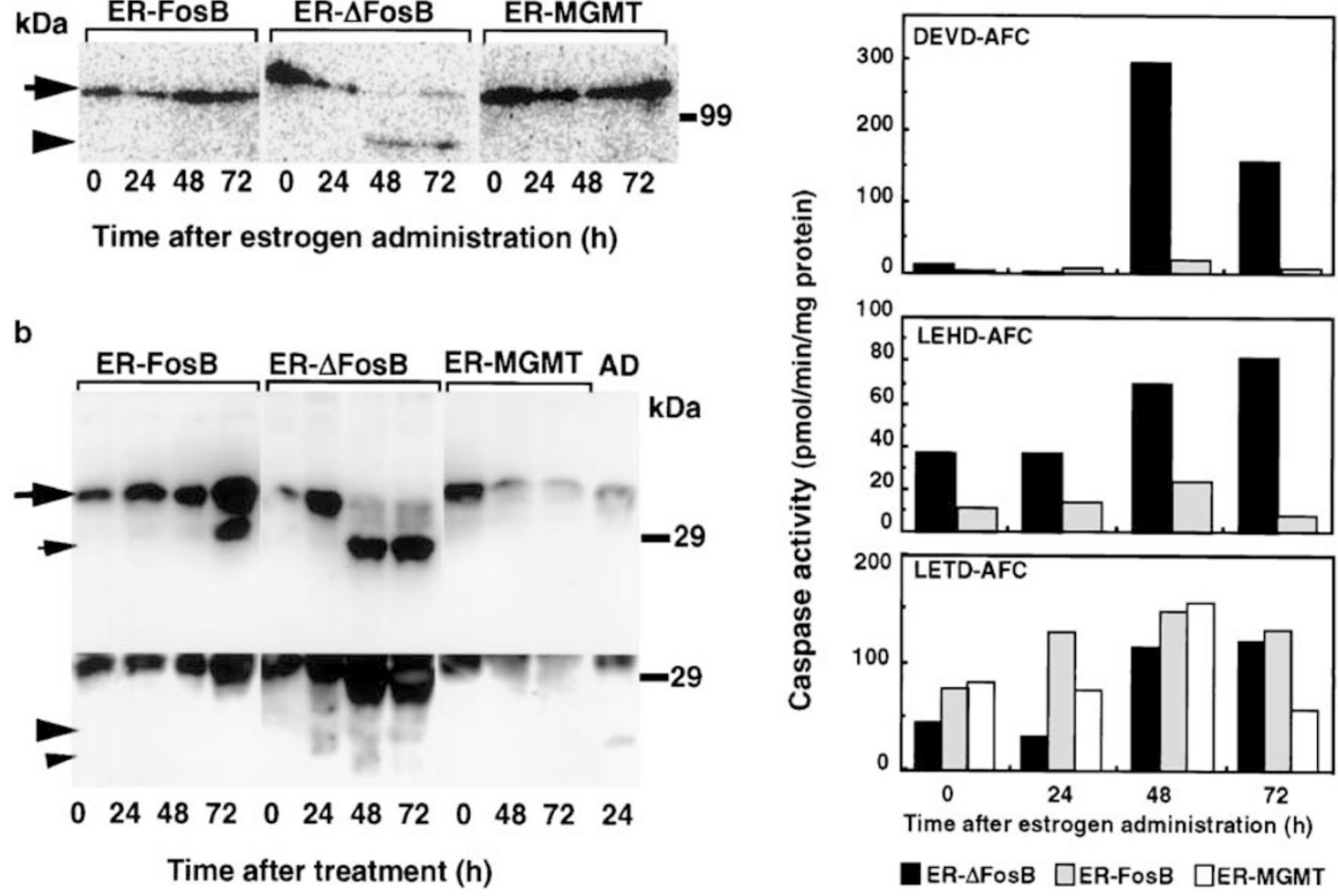

ER-AFosB DER-FosB DER-MGMt

Figure 6 The delayed cell death caused by ER- $\Delta$ FosB is accompanied by the activation of caspase-3 and caspase-9. (a) Processing of PARP. Quiescent Rat1a(ERFosB), Rat1a(ER- $\Delta$ FosB) and Rat1a(ER-MGMT) cells were treated with $1 \mu \mathrm{M}$ estrogen for the times noted. The cells were lysed and subjected to Western blotting with a polyclonal antibody against PARP (105 kDa, arrow). The arrowhead indicates the 85-kDa processed form of PARP. (b) Expression and processing of procaspase-3. Cell lysates prepared in (a) were subjected to Western blotting with polyclonal antibodies against caspase-3. As a positive control for processing procaspase-3, Rat1a(ER$\Delta$ FosB) cells were exposed to actinomycin D (2.5 ng/ml) for $24 \mathrm{~h}(\mathrm{AD})$. Upper panel, short exposure; lower panel, long exposure. The large arrow indicates the $32-\mathrm{kDa}$ precaspase-3, and the small arrow indicates a 24-kDa band. The arrowheads in the lower panel indicate the 20- and 17-kDa large subunits of caspase-3. (c) Caspase activities induced in Rat1a(ER- $\Delta$ FosB) cells during delayed cell death. Quiescent Rat1a(ER- $\Delta$ FosB) (closed bar), Rat1a(ER-FosB) (hatched bar), and Rat1a(ERMGMT) (open bar) cells were treated with $1 \mu \mathrm{M}$ estrogen for the times noted. Next, cell lysates were prepared and activities to hydrolyze DEVD-AFC (caspase-3 like), LEHD-AFC (caspase-9 like) and LETD-AFC (caspase-8) were determined

of galectin-1 expression in Rat1a(ER- $\Delta \mathrm{FosB})$ cells by antisense oligonucleotide or the inhibition of its lectin activity by lactose indicates that galectin- 1 is partly responsible for the cell proliferation induced by $\Delta \mathrm{FosB}$, but not for the delayed apoptosis. We would again like to emphasize that the galectin1 expression is altered in the process(es) of post-transcription by $\Delta F o s B$. Since galectin- 1 is expressed even in Rat1a(ERMGMT) cells whose proliferation was not altered by estrogen, it is likely that the galectin-1 expressed in Rat1a(ER- $\Delta$ FosB) cells in the presence of estrogen may have some different properties because of post-translational modification, such as oxidation or processing. ${ }^{15,36} \Delta$ FosB triggers the delayed apoptosis, most likely through one of the mitochondrial pathways, in which the cytochrome $c$ release from mitochondria is an upstream event leading to caspase- 9 and caspase- 3 activation. $^{29,30}$ Our data indicate that both caspase-9 and caspase-3, but not caspase-8, are essential for cell death in Rat1a(ER- $\Delta$ FosB) cells. The release of cytochrome $c$ from the mitochondria is the most upstream event related to apoptosis among those observed in the Rat $1 \mathrm{a}(\mathrm{ER}-\Delta \mathrm{FosB})$ cells, which became evident $48 \mathrm{~h}$ after estrogen treatment, and the amount of cytochrome $c$ released was much larger than that observed in the cells treated with staurosporine. About $40 \%$ of all Rat1a(ER- $\Delta$ FosB) cells treated with staurosporine underwent apoptosis $12 \mathrm{~h}$ after treatment, and a quarter of the dead cells were rescued by the administration of relatively small amounts of His-PTD-Bcl- $x_{\mathrm{L}},(84 \mathrm{nM})$, thus indicating that cytocrome $c$ release caused by staurosporine occurs through a pathway that can be suppressed by $\mathrm{Bcl}-\mathrm{x}_{\mathrm{L}}$, at least in part, as previously reported. ${ }^{37-39}$ The cell death caused by ER- $\Delta$ FosB is much more severe than that by staurosporine, probably reflecting the higher level of cytochrome $c$ release; however, cell death was not suppressed by the administration of large amounts of His-PTD-Bcl- $x_{L}$ protein $(600 \mathrm{nM})$. In Rat1a cells, various antiapoptotic and proapoptotic proteins such as Bcl-2, $\mathrm{Bcl}-\mathrm{x}_{\mathrm{L}}, \mathrm{Bax}, \mathrm{Bad}, \mathrm{Bid}^{30}$ are constitutively expressed regardless of the presence of either ER- $\Delta$ FosB expression or estrogen treatment. We thus suggest that $\Delta \mathrm{FosB}$, but not FosB, triggers an upstream event(s), which causes cytochrome $c$ release and is not suppressed by increasing the intracellular level of $\mathrm{Bcl}-\mathrm{x}_{\mathrm{L}}$.

Delayed cell death is a well-known phenomenon observed in the CA1 area of the hippocampus following forebrain ischemia in rodents, where CA1 neurons undergo apoptotic 
a

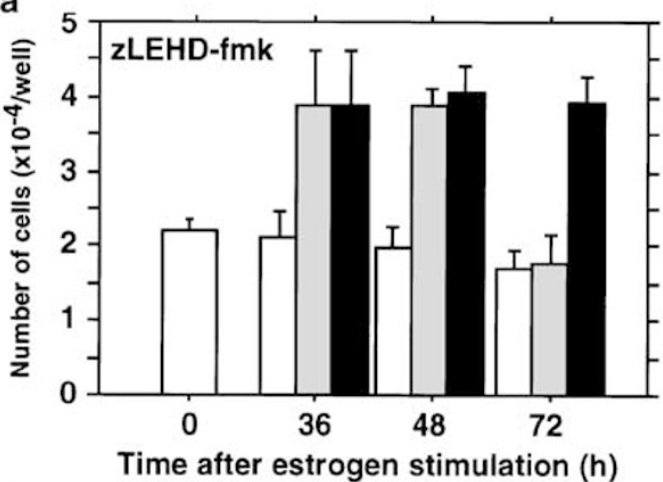

b

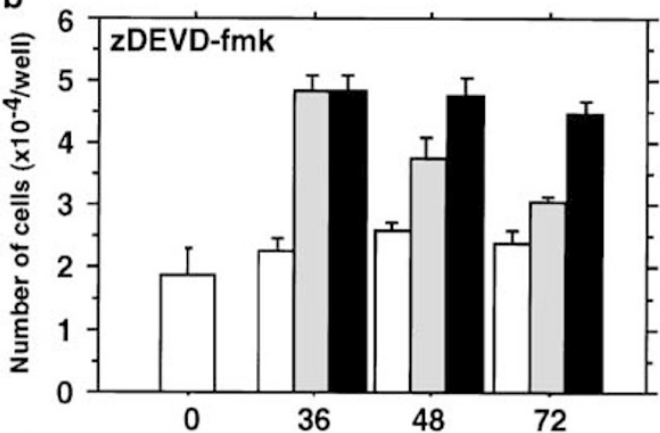

Time after estrogen stimulation (h)

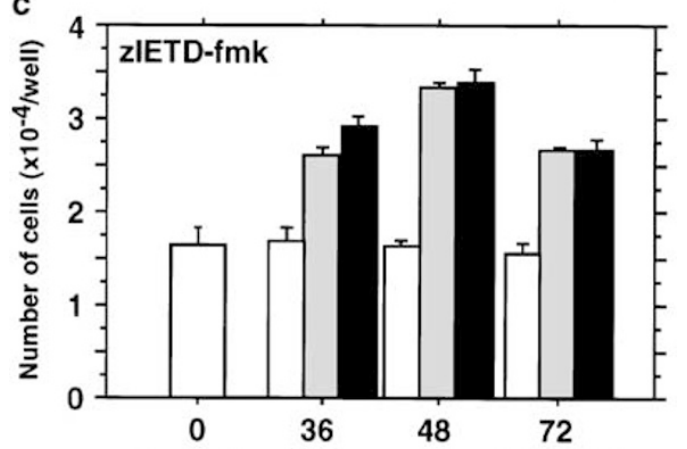

Time after estrogen stimulation (h)

$\square$ control ES

ES + inhibitor

Figure 7 Suppression of delayed cell death by caspase inhibitors. Quiescent Rat1a(ER- $\Delta$ FosB) cells were cultured with $1 \mu \mathrm{M}$ estrogen for $36 \mathrm{~h}$, and were then maintained in the absence (hatched bar) or presence (closed bar) of $20 \mu \mathrm{M}$ zLEHD-fmk (a), $40 \mu \mathrm{M}$ zDEVD-fmk (b) and $20 \mu \mathrm{M}$ zIETD-fmk (c). Open bar, control without estrogen and inhibitor. Cells were harvested at the times noted after estrogen administration, and living cells not stained with trypan blue were counted

cell death 3-4 days after insult. ${ }^{40}$ We previously reported that levels of FosB and $\Delta$ FosB are very low in the hippocampus of the control rat and are increased immediately in dentate gyrus and CA3 within a day after transient forebrain ischemia; however, in CA1, levels of $\triangle \mathrm{FosB}$ and the lesser extent of FosB increased more slowly together with c-Jun and reached the maximum just prior to the delayed cell death of CA1 neurons. ${ }^{16}$ Our present findings together with this observation suggest that an increased level of $\triangle \mathrm{FosB}$ in $\mathrm{CA} 1$ neurons is responsible for delayed neuronal cell death.

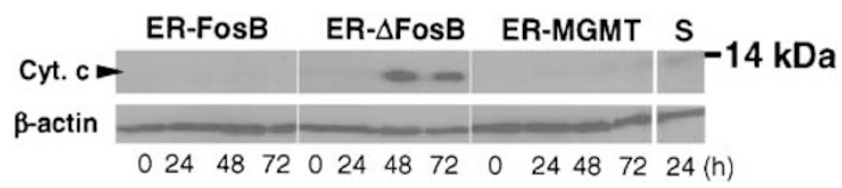

Figure 8 Cytochrome $c$ is released from mitochondria during the delayed cell death caused by ER- $\Delta$ FosB. Quiescent Rat1a(ER-FosB), Rat1a(ER- $\Delta$ FosB) and Rat1a(ER-MGMT) cells were treated with $1 \mu \mathrm{M}$ estrogen. Cells were harvested at the times noted, and the cytosolic fractions were prepared and subjected to Western blotting with a monoclonal antibody against cytochrome $c$ (an arrowhead in the upper panel). Rat1a(ER- $\Delta$ FosB) cells were also treated with $0.5 \mu \mathrm{M}$ staurosporine for $12 \mathrm{~h}$ in order to prepare a positive control for the cytochome $c$ release from mitochondria (S). The membrane was subsequently probed with anti- $\beta$-actin antibody (lower panel)

In adult gerbils or rats, high levels of $\mathrm{Bax}$ and $\mathrm{Bcl}-\mathrm{x}_{\mathrm{L}}$ were constitutively expressed in the CA1 area, while the level of $\mathrm{Bcl}-2$ and $\mathrm{Bcl}-\mathrm{x}_{\mathrm{s}}$ increased in dying $\mathrm{CA} 1$ neurons during the delayed neuronal death following forebrain ischemia, thus indicating that $\mathrm{Bcl}-\mathrm{x}_{\mathrm{L}}$ and $\mathrm{Bcl}-2$ were not sufficient to prevent nerve cells from dying. ${ }^{41}$ It has been shown that $\mathrm{Bcl}-\mathrm{x}_{\mathrm{s}}$ promotes apoptosis independent of both cytochrome $c$ and caspases; ${ }^{42}$ however, delayed neuronal death has been shown to be mostly caspase-9- and caspase-3-dependent accompanied by cytochrome $c$ release ${ }^{43-45}$ and this phenomenon is consistent with the delayed apoptosis triggered by $\Delta$ FosB.

We are presently screening both transcripts and proteins whose expressions are altered during the delayed apoptosis triggered by $\Delta$ FosB to elucidate the molecular pathway. $A$ better understanding of the molecular pathway in delayed apoptosis by $\triangle$ FosB may help to shed some light on the molecular mechanism of delayed neuronal death after the transient forebrain ischemia.

\section{Materials and Methods}

\section{Materials}

Estrogen ( $\beta$-estradiol), poly-L-lysine, lactose, fucose and actinomycin D were obtained from Sigma-Aldrich (St Louis, MO, USA). Caspase inhibitors, zDEVD-fmk, z-LEHD-fmk, z-IETD-fmk, and synthetic substrates for caspases, Ac-DEVD-AFC, Ac-LEHD-AFC, Ac-IETD-AFC, Ac-LETD-AFC, were purchased from Enzyme System Products (Livermore, CA, USA). DNA Ladder (1 kb), Prestained Protein Molecular Weight Standards, DMEM and FBS were purchased from Life Technologies (Bethesda, MD, USA). Rainbow Protein Molecular Weight Standards were products of Bio-Rad (Hercules, CA, USA). Low Range PFG Marker (2.03$194.0 \mathrm{~kb}$ ) was a product of New England Biolabs Inc. (Beverly, MA, USA). Hoechst33258, staurosporine and most of the other chemicals were obtained from Wako Pure Chemical Industries Ltd (Osaka, Japan). Hoechst33342 was a product of Carbiochem (San Diego, CA, USA). Butyrolactone I, an inhibitor for CDKs, was described previously. ${ }^{22}$ The sources of all other materials are indicated at the appropriate places in the text.

\section{Antibodies}

Rabbit polyclonal antibodies, anti-FosB(N) against FosB and $\triangle \mathrm{FosB}$, were used as previously described. ${ }^{5,13}$ Anti-rh Gal-1 was used to detect galectin-1, ${ }^{46}$ 
Table 1 Staurosporine-induced apotopsis is partially suppressed by His-PTD-Bcl- $\mathrm{X}_{\mathrm{L}}$

\begin{tabular}{lccc}
\hline Experiment & Apoptotic & Normal & \% Apoptosis \\
\hline No treatment & 3 & 339 & 0.8 \\
Buffer* & 3 & 366 & 0.8 \\
Staurosporine & 360 & 534 & 40.2 \\
Staurosporine+758 nM Bcl- $\mathrm{x}_{\mathrm{L}}^{\mathrm{a}}$ & 103 & 262 & 28.2 \\
Staurosporine+84 nM Bcl- $\mathrm{x}_{\mathrm{L}}$ & 81 & 194 & 29.4 \\
\hline
\end{tabular}

*The amount of stock buffer added to the medium was the same as that in a.Rat1a(ER- $\Delta \mathrm{FosB})$ cells were treated with $0.5 \mu \mathrm{M}$ staurosporine for $12 \mathrm{~h}$ in the presence or absence of His-PTD-Bcl- $\mathrm{x}_{\mathrm{L}}\left(\mathrm{Bcl}-\mathrm{x}_{\mathrm{L}}\right)$ protein in culture. Apoptotic cells were detected by Hoechst33342 staining.

Table $2 \Delta$ FosB-induced apotopsis is not suppressed by His-PTD-Bcl- $\mathrm{L}$

\begin{tabular}{|c|c|c|c|}
\hline Experiment & Apoptotic & Normal & $\%$ Apoptosis \\
\hline No treatment & 29 & 1410 & 2.0 \\
\hline Buffer* & 34 & 1544 & 2.2 \\
\hline Estrogen & 537 & 285 & 65.3 \\
\hline Estrogen+buffer* & 786 & 774 & 50.4 \\
\hline Estrogen+600 nM Bcl- $x_{L}(-2 h)^{a}$ & 1328 & 319 & 80.6 \\
\hline Estrogen+600 nM Bcl- $x_{L}(12 h)^{\prime}$ & 1100 & 418 & 72.5 \\
\hline Estrogen+600 nM Bcl- $x_{L}(24 h)$ & 707 & 125 & 85.0 \\
\hline
\end{tabular}

*The amount of stock buffer added to the medium was the same as that in a.Quiescent Rat1a(ER- $\Delta$ FosB) cells were exposed to His-PTD-Bcl- $x_{L}$ protein before $(-2 \mathrm{~h})$ or after $(12,24 \mathrm{~h}) 1 \mu \mathrm{M}$ estrogen administration. At $48 \mathrm{~h}$ after estrogen administration, apoptotic cells were detected by Hoechst33342 staining.

Rabbit polyclonal antibodies to caspase-3 (H-277), caspase-9 p10 (H83), $\mathrm{Bcl}-2(\mathrm{C}-2), \mathrm{Bcl}-\mathrm{x}_{\mathrm{L}}(\mathrm{H}-5)$, Bax (N-20), Bad (K-17), Bid (D-19) and PARP $(\mathrm{H}-$ 250) were purchased from Santa Cruz Biotechnology Inc. (Santa Cruz, CA, USA). Rabbit polyclonal antibodies to $\beta$-actin and mouse monoclonal antibody to cytochrome $c(7 \mathrm{H} 8.2 \mathrm{C} 12)$ were obtained from Sigma-Aldrich and BD PharMingen (San Diego, CA, USA), respectively. Horseradish peroxidase-labeled goat anti-mouse $\mathrm{IgG}$ was obtained from $\mathrm{BD}$ Transduction Laboratories (Lexington, KY, USA).

\section{Oligonucleotides}

Antisense oligonucleotide for rat galectin-1 mRNA (AS: 5'-CACAGGCCATGATTGAAG-3') and an oligonucleotide with a random sequence (RS: 5'-AGATCTTCTCAAGTGCTT-3') were purchased from Hokkaido System Science Co., Ltd (Sapporo, Japan). In each oligonucleotide, two phosphate residues at the $3^{\prime}$ and $5^{\prime}$ ends were replaced with phosphorothioates.

\section{Cell culture}

Rat1a cells transfected with pcDEB $\Delta, \operatorname{pcDEB} \Delta$ :ER-FosB and pcDEB$\Delta:$ ER- $\Delta$ FosB were designated as Rat1aH, Rat1a(ER-FosB) and Rat1a(ER- $\Delta$ FosB), respectively, and were maintained as previously described. ${ }^{13,18}$ To prepare serum-deprived quiescent cells, cells were grown to confluence and maintained in serum-free DMEM for 2 days. The quiescent cells were stimulated with $20 \%$ FBS or with $1 \mu \mathrm{M}$ estrogen. The number of viable cells in culture was counted using a hemocytometer, following staining with trypan blue.

\section{Pulse field gel electrophoresis}

The high molecular weight DNA fragmentation observed during apoptosis was examined by pulse field gel electrophoresis, as previously described. $^{47}$

\section{Detection of oligonucleosomal fragmentation}

Both the DNA extraction and agarose gel electrophoresis for the detection of oligonucleosomal fragmentation were performed as described. ${ }^{48}$

\section{Western blotting}

Nuclear and cytoplasmic lysates for the detection of ER-FosB and ER$\triangle$ FosB by Western blotting analysis were prepared and the UV absorbance (A260, A280) of each lysate at 260 and $280 \mathrm{~nm}$ was measured, as described. ${ }^{13}$ Cell lysates to detect galectin-1 and PARP were prepared by sonicating cells in a lysis buffer $(20 \mathrm{mM}$ Tris- $\mathrm{HCl}, \mathrm{pH} 7.5$, $1 \%$ SDS, $2 \mathrm{mM}$ EDTA, $2 \mathrm{mM}$ EGTA, $6 \mathrm{mM} \beta$-mercaptoethanol, $1 \mathrm{mM}$ PMSF, $25 \mu \mathrm{g} / \mathrm{ml}$ pepstatin and $25 \mu \mathrm{g} / \mathrm{ml}$ leupeptin). To detect caspases by Western blotting, harvested cells were suspended in a lysis buffer $(10 \mathrm{mM}$ Tris- $\mathrm{HCl}$, pH 7.4, $1 \mathrm{mM}$ EDTA, $1 \mathrm{mM}$ EGTA, 1\% Triton X-100, $2 \mathrm{mM}$ sodium orthovanadate, $1 \mathrm{mM}$ PMSF, $25 \mu \mathrm{g} / \mathrm{ml}$ pepstatin and $25 \mu \mathrm{g} / \mathrm{ml}$ leupeptin), and were incubated for $15 \mathrm{~min}$ on ice. Next, the lysate was centrifuged at $15000 \mathrm{~g}$ for $10 \mathrm{~min}$ at $4^{\circ} \mathrm{C}$, and the supernatant was recovered. Proteins were separated on SDS-PAGE and transferred onto Immobilon-P membrane (Millipore Corporation, Bedford, MA, USA), and the membranes were subjected to Western blotting, according to a previously described procedure. ${ }^{49}$ Primary antibodies were used with a combination of horseradish peroxidase-labeled protein A (Amersham 
Pharmacia Biotech) or horseradish peroxidase-labeled goat anti-mouse IgG, and the antibodies bound to each blot were detected using a chemiluminescence method with the ECL-Plus Kit (Amersham Pharmacia Biotech). Digitized images were obtained by LAS1000 Plus (Fuji Photo Film Co. Ltd, Tokyo, Japan) and processed for publication using the Adobe Photoshop 5.5J software package (Adobe Systems).

\section{Northern blotting analysis}

Total cellular RNA was isolated using an isogen kit (Nippon Gene, Tokyo, Japan). Northern blotting was performed using an $\alpha^{32}$ P-labeled probe as previously described. ${ }^{18}$ Radioactivity on the membrane was measured in a Bio-image analyzer (model BAS 2000, Fuji Photo Film Co. Ltd), and digitized images were processed for publication using the Adobe Photoshop 5.5J.

\section{Flow cytometry}

The cells were collected and resuspended in $0.5 \mathrm{ml}$ of $3.4 \mathrm{mM}$ sodium citrate, $10 \mathrm{mM} \mathrm{NaCl}, 0.1 \% \mathrm{NP}-40,50 \mu \mathrm{g} / \mathrm{ml}$ propidium iodide to stain nuclear DNA. The fluorescence intensity in the cell nucleus was measured with a FACScalibur (Becton Dickinson). For each sample, 10000 cells were analyzed and the results were processed using the Cell Quest computer program (Becton Dickinson). Percentages of the cells in the subG1 fraction were calculated by ModFit software (Becton Dickinson).

\section{Caspase assay}

Cell lysates for caspase assay were prepared as described ${ }^{50}$ with a slight modification. Harvested cells $\left(2.7 \times 10^{7}\right)$ were suspended in $50 \mu \mathrm{l}$ of a lysis buffer (50 mM KC1, $50 \mathrm{mM}$ Pipes, pH 7.0, $10 \mathrm{mM}$ EGTA, $2 \mathrm{mM}$ $\mathrm{MgCl}_{2}, 20 \mathrm{mM}$ cytochalasin B, $1 \mathrm{mM}$ PMSF, $10 \mathrm{mM}$ DTT) in a small Dounce homogenizer, and the suspension was subjected to several cycles of freezing and thawing in liquid nitrogen. During each thawing cycle, the cells were further disrupted by grinding with a pestle at room temperature. The lysate was centrifuged at $14000 \mathrm{~g}, 4^{\circ} \mathrm{C}$ for $15 \mathrm{~min}$, and then the supernatent was recovered, and stored at $-80^{\circ} \mathrm{C}$. Cleavage of DEVDAFC by caspase-3 or caspase-3- like activity was assayed as follows. Lysate (30 $\mu \mathrm{g}$ of protein) was incubated in $500 \mu \mathrm{l}$ of buffer (0.1 M HEPES, $\mathrm{pH} 7.4,2 \mathrm{mM}$ DTT, $0.1 \%$ CHAPS, $1 \%$ sucrose) containing $200 \mu \mathrm{M} \mathrm{Ac}$ DEVD-AFC and incubated at room temperature. To measure the caspase9 activity, lysate ( $50 \mu \mathrm{g}$ of protein) was incubated in $500 \mu \mathrm{l}$ of buffer (100 mM HEPES, pH 7.5, 20\% glycerol, $5 \mathrm{mM}$ DTT, $0.5 \mathrm{mM}$ EDTA) containing $200 \mu \mathrm{M} \mathrm{Ac-LEHD-AFC}$ and incubated at room temperature. To measure the caspase- 8 activity, lysate ( $50 \mu \mathrm{g}$ of protein) was incubated in $500 \mu \mathrm{l}$ of the same buffer containing $200 \mu \mathrm{M}$ Ac-IETD-AFC and incubated at room temperature. In each reaction, the release of free AFC was monitored using fluorometer (RF5300PC, Shimadzu, Kyoto, Japan) settings of $400 \mathrm{~nm}$ excitation and $505 \mathrm{~nm}$ emission until a significant amount of fluorescence had been generated. Standards containing 0 $1200 \mathrm{pmol}$ of AMC were utilized to determine the amount of fluorochrome released. Control experiments (not shown) confirmed that the release of substrate was linear over time and for the protein concentration under the specified conditions.

\section{Electron microscopy}

The cells $\left(2 \times 10^{7}\right)$ were suspended in $5 \mathrm{ml}$ of PBS, combined with $5 \mathrm{ml}$ of fixing buffer ( $5 \%$ glutaraldehyde, $0.2 \mathrm{M}$ sucrose, $6 \mathrm{mM} \mathrm{CaCl}_{2}$ in $0.2 \mathrm{M}$ cacodylate buffer, $\mathrm{pH} 7.4$ ), and kept for $10 \mathrm{~min}$ at $37^{\circ} \mathrm{C}$. The cell pellets were processed through $1 \% \mathrm{OsO}_{4}$ for 30 min at $4{ }^{\circ} \mathrm{C}$, dehydrated in graded ethanol and propylene oxide, and then embedded in Epon 812 resin. Thin sections were stained with $2 \%$ uranyl acetate for $60 \mathrm{~min}$ and lead acetate for $5 \mathrm{~min}$ and thereafter were examined under a JEM-2000EX electron microscope, as previously described. ${ }^{19}$

\section{Fluorochrome staining of cells}

The cells were placed on poly-L-lysine-pretreated four-well LAB-TEK chamber slides (Nalge Nunc, International, Naperville, IL, USA), and then were fixed and stained with Hoechst33258 $(5 \mu \mathrm{g} / \mathrm{ml})$, as described. ${ }^{48}$ Living cells on cultured dish were incubated with Hoechst33342 $(10 \mu \mathrm{g} / \mathrm{ml})$ in medium for $30 \mathrm{~min}$ at $37^{\circ} \mathrm{C}$. Phase-contrast figures and fluorochromes were observed under Axiovert $135 \mathrm{M}$ microscope (Carl Zeiss, Inc., Germany). Digitized images were obtained by a digital camera (FinePix SI Pro, Fuji Photo Film Co. Ltd) and were then processed for publication using Adobe Photoshop 5.5J.

\section{Analysis of cytochrome $c$ release}

The cytosolic fraction was prepared as described. ${ }^{29}$ Briefly, harvested cells were resuspended in five volumes of ice-cold buffer $(250 \mathrm{mM}$ sucrose, $20 \mathrm{mM}$ HEPES-KOH pH 7.5, $5 \mu \mathrm{g} / \mathrm{ml}$ pepstatin A, $10 \mu \mathrm{g} / \mathrm{ml}$ leupeptin), incubated for $15 \mathrm{~min}$ on ice, and homogenized in Potter's homogenizer for five strokes. The homogenate was centrifuged at $1000 \mathrm{~g}$ for $10 \mathrm{~min}$ at $4^{\circ} \mathrm{C}$, and the supernatant was further centrifuged at $100000 \mathrm{~g}$ for $30 \mathrm{~min}$ at $4{ }^{\circ} \mathrm{C}$. The cleared supernatant was recovered as the cytosolic fraction. Cytochrome $c$ released in the cytosolic fraction was detected by Western blotting using the mouse monoclonal antibody to cytochrome $c$ (7H8.2C12).

\section{Preparation of His-PTD-Bcl- $\mathrm{x}_{\mathrm{L}}$ protein}

An oligonucleotide encoding MGYGRKKRRQRRRG (the 11-amino acid Tat PTD is underlined $)^{51}$ was ligated to the $5^{\prime}$-end of the $B c l-x_{L}$ coding sequence ${ }^{52}$ by PCR to construct PTD-Bcl- $\mathrm{X}_{\mathrm{L}}$. The ligated DNA fragment was inserted between the Ndel and Hind III sites in the PPROEX-1 expression vector (In vitrogen Life Technologies, Carlsbad, CA, USA) to obtain His-tagged PTD-Bcl- $\mathrm{x}_{\mathrm{L}}$ (His-PTD-Bcl- $\mathrm{x}_{\mathrm{L}}$ ). The integrity of the construct was confirmed by sequencing. The fusion protein His-PTD-Bcl$\mathrm{X}_{\mathrm{L}}$ was expressed in $E$. coli $\mathrm{DH} 5 \alpha$ and was purified as previously described..$^{30}$ Purified His-PTD-Bcl- $x_{\mathrm{L}}$ protein $(56.8 \mu \mathrm{M})$ was stored in the stock buffer (PBS containing $8 \mathrm{M}$ urea, $10 \%$ glycerol, $1 \mathrm{mM} \beta$ mercaptoethanol).

\section{Determination of the protein concentration}

The protein concentration was determined using a Bio-Rad protein assay kit (Bio-Rad) and BSA as standard.

\section{Acknowledgements}

We extend our special thanks to M Furuichi, K Sakumi, M Ohno, P Xu, T Miura and $Y$ Ohnishi for helpful discussions, M Sasaki for electron microscopy, and B Quinn for useful comments on this manuscript. This work was supported in part by Grant-in-Aids for Scientific Research from the Ministry of Education, Culture, Sports, Science and Technology of Japan and the Japan Society for the Promotion of Science. 


\section{References}

1. Nakabeppu Y, Ryder K and Nathans D (1988) DNA binding activities of three murine Jun proteins: stimulation by Fos. Cell 55: 907-915

2. Chinenov Y and Kerppola TK (2001) Close encounters of many kinds: Fos-Jun interactions that mediate transcription regulatory specificity. Oncogene 20: 2438-2452

3. Jochum W, Passegue E and Wagner EF (2001) AP-1 in mouse development and tumorigenesis. Oncogene 20: 2401-2412

4. Shaulian E and Karin M (2001) AP-1 in cell proliferation and survival. Oncogene 20: $2390-2400$

5. Nakabeppu $Y$ and Nathans D (1991) A naturally occurring truncated form of FosB that inhibits Fos/Jun transcriptional activity. Cell 64: 751-759

6. Chen J, Kelz MB, Hope BT, Nakabeppu Y and Nestler EJ (1997) Chronic Fosrelated antigens: stable variants of $\triangle \mathrm{FosB}$ induced in brain by chronic treatments. J. Neurosci. 17: 4933-4941

7. Sabatakos G, Sims NA, Chen J, Aoki K, Kelz MB, Amling M, Bouali Y, Mukhopadhyay K, Ford K, Nestler EJ and Baron R (2000) Overexpression of $\triangle$ FosB transcription factor(s) increases bone formation and inhibits adipogenesis. Nat. Med. 6: 985-990

8. Metz R, Kouzarides T and Bravo R (1994) A C-terminal domain in FosB, absent in FosB/ SF and Fra-1, which is able to interact with the TATA binding protein, is required for altered cell growth. EMBO J. 13: 3832-3842

9. Herdegen T and Leah JD (1998) Inducible and constitutive transcription factors in the mammalian nervous system: control of gene expression by Jun, Fos and Krox, and CREB/ ATF proteins. Brain Res. Rev. 28: 370-490

10. Hope BT, Nye HE, Kelz MB, Self DW, ladarola MJ, Nakabeppu Y, Duman RS and Nestler EJ (1994) Induction of a long-lasting AP-1 complex composed of altered Fos-like proteins in brain by chronic cocaine and other chronic treatments. Neuron 13: 1235-1244

11. Chen J, Nye HE, Kelz MB, Hiroi N, Nakabeppu Y, Hope BT and Nestler EJ (1995) Regulation of $\Delta$ FosB and FosB-like proteins by electroconvulsive seizure and cocaine treatments. Mol. Pharmacol. 48: 880-889

12. Doucet JP, Nakabeppu Y, Bedard PJ, Hope BT, Nestler EJ, Jasmin BJ, Chen JS, ladarola MJ, St-Jean M, Wigle N, Blanchet P, Grondin R and Robertson GS (1996) Chronic alterations in dopaminergic neurotransmission produce a persistent elevation of $\Delta$ FosB-like protein(s) in both the rodent and primate striatum. Eur. J. Neurosci. 8: 365-381

13. Nakabeppu Y, Oda S and Sekiguchi M (1993) Proliferative activation of quiescent Rat-1A cells by $\Delta$ FosB. Mol. Cell. Biol. 13: 4157-4166

14. Crocker SJ, Morelli M, Wigle N, Nakabeppu Y and Robertson GS (1998) DIreceptor-related priming is attenuated by antisense-mediated 'knockdown' of fosB expression. Mol. Brain Res. 53: 69-77

15. Nishioka T, Sakumi K, Miura T, Tahara K, Horie H, Kadoya T and Nakabeppu Y (2002) fosB gene products trigger cell proliferation and morphological alteration with an increased expression of a novel processed form of galectin-1 in the rat $3 Y 1$ embryo cell line. J. Biochem. 131: 653-661

16. McGahan L, Hakim AM, Nakabeppu Y and Robertson GS (1998) Ischemiainduced CA1 neuronal death is preceded by elevated FosB and Jun expression and reduced NGFI-A and JunB levels. Mol. Brain Res. 56: 146-161

17. Ishibashi T, Nakabeppu $Y$ and Sekiguchi M (1994) Artificial control of nuclear translocation of DNA repair methyltransferase. J. Biol. Chem. 269: 7645-7650

18. Oda S, Nishida J, Nakabeppu Y and Sekiguchi M (1995) Stabilization of cyclin $\mathrm{E}$ and cdk2 mRNAs at G1/S transition in Rat-1A cells emerging from the G0 state. Oncogene 10: 1343-1351

19. Lu YY, Koga Y, Tanaka K, Sasaki M, Kimura G and Nomoto K (1994) Apoptosis induced in $\mathrm{CD} 4^{+}$cells expressing gp 160 of human immunodeficiency virus type 1. J. Virol. 68: 390-399

20. Pandey $S$ and Wang $E$ (1995) Cells en route to apoptosis are characterized by the upregulation of c-fos, c-myc, c-jun, cdc2, and RB phosphorylation, resembling events of early cell-cycle traverse. J. Cell. Biochem. 58: 135-150

21. Furukawa Y, Iwase S, Terui Y, Kikuchi J, Sakai T, Nakamura M, Kitagawa S and Kitagawa M (1996) Transcriptional activation of the cdc2 gene is associated with Fas-induced apoptosis of human hematopoietic cells. J. Biol. Chem. 271: 28469-28477

22. Kitagawa M, Okabe T, Ogino H, Matsumoto H, Suzuki-Takahashi I, Kokubo T, Higashi H, Saitoh S, Taya Y, Yasuda H, Ohba Y, Nishimura S, Tanaka N and Okuyama A (1993) Butyrolactone I, a selective inhibitor of cdk2 and cdc2 kinase. Oncogene 8: 2425-2432
23. Perillo NL, Pace KE, Seilhamer JJ and Baum LG (1995) Apoptosis of T cells mediated by galectin-1. Nature 378: 736-739

24. Yamaoka K, Mishima K, Nagashima Y, Asai A, Sanai Y and Kirino T (2000) Expression of galectin-1 mRNA correlates with the malignant potential of human gliomas and expression of antisense galectin- 1 inhibits the growth of 9 glioma cells. J. Neurosci. Res. 59: 722-730

25. Cohen GM (1997) Caspases: the excecutioners of apoptosis. Biochem. J. 326 : 1-16

26. Kamradt MC, Chen F and Cryns VL (2001) The small heat shock protein $\alpha B$ crystallin negatively regulates cytochrome $c$ - and caspase-8-dependent activation of caspase-3 by inhibiting its autoproteolytic maturation. J. Biol. Chem. 276: 16059-16063

27. Thornberry NA, Rano TA, Peterson EP, Rasper DM, Timkey T, Garcia-Calvo M, Houtzager VM, Nordstrom PA, Roy S, Vaillancourt JP, Chapman KT and Nicholson DW (1997) A combinatorial approach defines specificities of members of the caspase family and granzyme B. Functional relationships established for key mediators of apoptosis. J. Biol. Chem. 272: 17907-17911

28. Garcia-Calvo M, Peterson EP, Leiting B, Ruel R, Nicholson DW and Thornberry NA (1998) Inhibition of human caspases by peptide-based and macromolecular inhibitors. J. Biol. Chem. 273: 32608-32613

29. Li P, Nijhawan D, Budihardjo I, Srinivasula SM, Ahmad M, Alnemri ES and Wang X (1997) Cytochrome $C$ and dATP-dependent formation of Apaf-I/ caspase-9 complex initiates an apoptotic protease cascade. Cell 91: 479-489

30. Joza N, Kroemer $G$ and Penninger JM (2002) Genetic analysis of the mammalian cell death machinery. Trends Genet. 18: 142-149

31. Embury J, Klein D, Pileggi A, Ribeiro M, Jayaraman S, Molano RD, Fraker C, Kenyon N, Ricordi C, Inverardi L and Pastori RL (2001) Proteins linked to a protein transduction domain efficiently transduce pancreatic islets. Diabetes 50: 1706-1713

32. Cao G, Pei W, Ge H, Liang Q, Luo Y, Sharp FR, Lu A, Ran R, Graham SH and Chen J (2002) In vivo delivery of a Bcl- $x_{L}$ fusion protein containing the TAT protein transduction domain protects against ischemic brain injury and neuronal apoptosis. J. Neurosci. 22: 5423-5431

33. Yamamura Y, Hua X, Bergelson S and Lodish HF (2000) Critical role of Smads and AP-1 complex in transforming growth factor- $\beta$-dependent apoptosis. $\mathrm{J}$. Biol. Chem. 275: 36295-36302

34. Moiseeva EP, Javed Q, Spring EL and de Bono DP (2000) Galectin 1 is involved in vascular smooth muscle cell proliferation. Cardiovasc. Res. 45: 493-502

35. Rabinovich GA, Alonso CR, Sotomayor CE, Durand S, Bocco JL and Riera CM (2000) Molecular mechanisms implicated in galectin-1-induced apoptosis: activation of the AP-1 transcription factor and downregulation of Bcl-2. Cell Death Differ. 7: 747-753

36. Horie $\mathrm{H}$ and Kadoya $\mathrm{T}$ (2000) Identification of oxidized galectin-1 as an initial repair regulatory factor after axotomy in peripheral nerves. Neurosci. Res. 38: $131-137$

37. Vander Heiden MG, Chandel NS, Williamson EK, Schumacker PT and Thompson CB (1997) Bcl- $\mathrm{X}_{\mathrm{L}}$ regulates the membrane potential and volume homeostasis of mitochondria. Cell 91: 627-637

38. Kim JE, Oh JH, Choi WS, Chang, II, Sohn S, Krajewski S, Reed JC, O'Malley KL and Oh YJ (1999) Sequential cleavage of poly(ADP-ribose)polymerase and appearance of a small Bax-immunoreactive protein are blocked by $B c l-X_{L}$ and caspase inhibitors during staurosporine-induced dopaminergic neuronal apoptosis. J. Neurochem. 72: 2456-2463

39. Asoh S, Ohtsu T and Ohta S (2000) The super anti-apoptotic factor Bcl- $\mathrm{X}_{\mathrm{FNK}}$ constructed by disturbing intramolecular polar interactions in rat Bcl- $\mathrm{x}_{\mathrm{L}}$. J. Biol. Chem. 275: 37240-37245

40. Kirino $T$ (1982) Delayed neuronal death in the gerbil hippocampus following ischemia. Brain Res. 239: 57-69

41. Ferrer I, Lopez E, Blanco R, Rivera R, Ballabriga J, Pozas E and Marti E (1998) $\mathrm{Bcl}-2$, Bax, and Bcl-x expression in the CA1 area of the hippocampus following transient forebrain ischemia in the adult gerbil. Exp. Brain Res. 121: 167-173

42. Fridman JS, Parsels J, Rehemtulla A and Maybaum J (2001) Cytochrome $c$ depletion upon expression of Bcl- $\mathrm{X}_{\text {s. }}$ J. Biol. Chem. 276: 4205-4210

43. Antonawich FJ (1999) Translocation of cytochrome $\mathrm{c}$ following transient global ischemia in the gerbil. Neurosci. Lett. 274: 123-126

44. Xu D, Bureau Y, Mclntyre DC, Nicholson DW, Liston P, Zhu Y, Fong WG, Crocker SJ, Korneluk RG and Robertson GS (1999) Attenuation of 
ischemia-induced cellular and behavioral deficits by X chromosome-linked inhibitor of apoptosis protein overexpression in the rat hippocampus. J. Neurosci. 19: 5026-5033

45. Cao G, Luo Y, Nagayama T, Pei W, Stetler RA, Graham SH and Chen J (2002) Cloning and characterization of rat caspase-9: implications for a role in mediating caspase-3 activation and hippocampal cell death after transient cerebral ischemia. J. Cereb. Blood Flow Metab. 22: 534-546

46. Horie H, Inagaki $Y$, Sohma $Y$, Nozawa R, Okawa K, Hasegawa M, Muramatsu N, Kawano H, Horie M, Koyama H, Sakai I, Takeshita K, Kowada Y, Takano M and Kadoya T (1999) Galectin-1 regulates initial axonal growth in peripheral nerves after axotomy. J. Neurosci. 19: 9964-9974

47. Samejima K, Tone S, Kottke TJ, Enari M, Sakahira H, Cooke CA, Durrieu F, Martins LM, Nagata S, Kaufmann SH and Earnshaw WC (1998) Transition from caspase-dependent to caspase-independent mechanisms at the onset of apoptotic execution. J. Cell Biol. 143: 225-239

48. Tominaga Y, Tsuzuki T, Shiraishi A, Kawate H and Sekiguchi M (1997) Alkylation-induced apoptosis of embryonic stem cells in which the gene for
DNA-repair, methyltransferase, had been disrupted by gene targeting. Carcinogenesis 18: 889-896

49. Tsuchimoto D, Sakai Y, Sakumi K, Nishioka K, Sasaki M, Fujiwara T and Nakabeppu Y (2001) Human APE2 protein is mostly localized in the nuclei and to some extent in the mitochondria, while nuclear APE2 is partly associated with proliferating cell nuclear antigen. Nucleic Acids Res. 29: 2349-2360

50. Lazebnik YA, Cole S, Cooke CA, Nelson WG and Earnshaw WC (1993) Nuclear events of apoptosis in vitro in cell-free mitotic extracts: a model system for analysis of the active phase of apoptosis. J. Cell Biol. 123: 7-22

51. Nagahara H, Vocero-Akbani AM, Snyder EL, Ho A, Latham DG, Lissy NA, Becker-Hapak M, Ezhevsky SA and Dowdy SF (1998) Transduction of fulllength TAT fusion proteins into mammalian cells: TAT-p27Kip 1 induces cell migration. Nat. Med. 4: 1449-1452

52. Shiraiwa N, Inohara N, Okada S, Yuzaki M, Shoji S and Ohta S (1996) An additional form of rat $\mathrm{Bcl}-\mathrm{x}, \mathrm{Bcl}-\mathrm{x} \beta$, generated by an unspliced RNA, promotes apoptosis in promyeloid cells. J. Biol. Chem. 271: 13258-13265 